Relations industrielles

Industrial Relations

\title{
Management at the Bargaining Table, by K.O. Warner \& M.L. Hennessy, Public Personnel Association, Chicago, 1967, 490 pp.
}

\section{Jean Sexton}

Volume 23, numéro 1, 1968

URI : https://id.erudit.org/iderudit/027875ar

DOI : https://doi.org/10.7202/027875ar

Aller au sommaire du numéro

Éditeur(s)

Département des relations industrielles de l'Université Laval

ISSN

0034-379X (imprimé)

1703-8138 (numérique)

Découvrir la revue

Citer ce compte rendu

Sexton, J. (1968). Compte rendu de [Management at the Bargaining Table, by K.O. Warner \& M.L. Hennessy, Public Personnel Association, Chicago, 1967, 490 pp.] Relations industrielles / Industrial Relations, 23(1), 178-178.

https://doi.org/10.7202/027875ar

Tous droits réservés (C) Département des relations industrielles de l'Université Laval, 1968
Ce document est protégé par la loi sur le droit d'auteur. L’utilisation des services d'Érudit (y compris la reproduction) est assujettie à sa politique d'utilisation que vous pouvez consulter en ligne.

https://apropos.erudit.org/fr/usagers/politique-dutilisation/ 
of government intervention. This includes legislative enactment, administrative procedure, and judicial pronouncement.

Experience in the United States has ranged from governmental passivity to congressional compulsion in the railroad controversy. Of zourse there are many intermediate positions of government persuation and force.

To those who are interested in the deliniation of the proper scope of intervention of governmental activity and the weight to be accorded the role of public welfare in labor disputes, this publication is recommended. It will be of assistance in informing the reader of the current development in the United States in this sector of industrial relations.

\section{Benjamin S. KIRSH}

Management at the Bargaining Table, by K.O. Warner \& M.L. Hennessy, Public Personnel Association, Chicago, 1967, $490 \mathrm{pp}$.

II y a peu de secteurs dans I'administration publique qui soient plus fluides et plus dynamiques que le domaine des relations patronales-ouvrières. Les auteurs de ce volume considèrent les relations entre la direction des entreprises publiques et les organisations d'employés comme un phénomène en constante évolution.

L'élément le plus important dans le phéomène des relations patronales-ouvrières dans le secteur public est en fait la négociation collective. Ce concept est assez récent dans les services publics et relativement non développé dans l'histoire de l'administration publique. Warner et Hennessy croient qu'il est temps de présenter une analyse plus systématique du Comportement de la direction des entreprises publiques à la table des négociations.

Sans prétendre que ce livre soit une étude définitive et finale, on peut quand même dire qu'il présente une introduction d'assez large envergure à un sujet $d^{\prime}$ intérêt croissant. Cet ouvrage comporte 3 grandes parties. En premier lieu, "The Dynamics of Collective Bargaining ", présente la direction des entreprises publiques et quasi-publiques. Ce chapitre ne se limite pas seulement au gouvernement, mais il touche les universités, les écoles publiques et les corporations publiques. Puis on rencontre dans "The Bargaining Process » l'employé organisé en syndicat, en association indépendante ou en association professionnelle. C'est dans \& The Future of Collective Bargaining "que les auteurs considèrent le problème dans l'optique du public, des payeurs de taxes qui reçoivent des services en retour des argents versés.

Même si ce livre étudie le problème de la négociation collective surtout dans l'optique de la direction des entreprises publiques, son contenu touche autant le public que les organisations de travailleurs.

Cette monographie n'est donc pas seulement un livre de recettes. Elle décrit le cadre à l'intérieur duquel la direction des entreprises publiques négocie avec les organisations d'employés et en plus rend compte des pratiques courantes. Les outeurs y offrent en plus des suggestions protiques sur la planification et la conduite de la négociation collective et sur les politiques et décisions à prendre pour conserver des relations harmonieuses avec les organisations d'employés.

En plus, les auteurs avoncent un certain nombre de conclusions sur l'avenir des négociations dans les services publics et ce que cet avenir peut réserver aux administrateurs publics. Disons finalement que ce livre présente en annexe une foule de documents qui permettent autant à l'étudiant qu'au proticien d'élargir ses horizons sur le sujet.

\section{Jean SEXTON}

Teachers, School Boards and Collective Bargaining: A Changing of the Guard, by Robert E. Doherty and Walter E. Oberer, Cornell University, Ithaca, N.Y., May 1967, 139 pages.

The authors of this book are qualified as experts in the new field of collective bargoining in public educotion. Both have picked up their briefcases and travelled on many occasions, one to serve as a moderator and arbitrator in teacher representation and bargaining disputes, the other to conduct conferences and workshops in employeremployee relations for school-board members, school administrators, and teachers.

This book was written during the summer of 1966. Thus, their findings are based on very recent history, an era that educational historian of the future will likely call the seminal period of formal collective employment arrangements in education. So, this booklet may serve as an alarm to those concerned with providing a more appropriate structure for teacher-school board relations in a time of somewhat chaotic, but creative, flux. 